\title{
Reconciling Evolution and Biblical Literalism: A Proposed Research Program
}

\section{ABSTRACT}

Many leading Christian thinkers today accept evolution, but others worry that certain incompatibilities with Biblical doctrines concerning Adam remain. In Should Christians Embrace Evolution, theologian Wayne Grudem succinctly summarizes their main objections when he claims that adopting evolution leads to eight positions contrary to the teaching of the Bible. In response, I show that, regardless of whether evolution occurred or not, there is no incompatibility even when a consistently literal reading of the relevant Biblical texts is maintained.

Keywords: evolution, creation, Bible, Adam, image of God, hominids

Author:

Dr Andrew Ter Ern Loke

Research Assistant Professor

Faith and Global Engagement, The University of Hong Kong

Bio

Dr Loke is Research Assistant Professor at The University of Hong Kong. He did his Bachelor in Medicine at National University of Singapore, his Masters in Philosophy at Biola University and his $\mathrm{PhD}$ in Theology at King's College London. He is the author of 'Science and Christian Faith' (2016), 'A Kryptic Model of the Incarnation' (2014), and various articles in leading international journals such as Australasian Journal of Philosophy, Religious Studies (Cambridge University 
Press) and Journal of Theological Studies (Oxford University Press). He has spoken at conferences, universities, seminaries and churches internationally.

\section{INTRODUCTION}

'I think the evangelical Christians have really sort of got it right in a way, in seeing evolution as the enemy. Whereas the more, what shall we say, sophisticated theologians are quite happy to live with evolution, I think they are deluded. I think the evangelicals have got it right, in that there is a deep incompatibility between evolution and Christianity, and I think I realized that about the age of sixteen’-Richard Dawkins ${ }^{1}$

Many atheists and Christians think that evolution and Christianity are incompatible, and the question whether the theory of evolution is compatible with biblical doctrines has been heavily debated in recent literature. ${ }^{2}$ The situation among evangelical Christians, however, is not as simple as what Dawkins seems to think, as quite a number of leading Christian theologians, biblical scholars, apologists, philosophers, scientists and church leaders past and present who have been identified as evangelicals, such as Benjamin Warfield, J.I. Packer, John Stott, Alister McGrath, John Walton, Bruce Walke, Alvin Plantinga, William Lane Craig, John Polkinghorne, Owen Gingerich, Francis Collins, Dennis Alexander and Tim Keller have answered in the affirmative. Nevertheless, there are others who remain unconvinced. They point out that the issue cannot be settled simply by saying that 'God could have created through evolution.' In Should Christians Embrace Evolution, theologian Wayne Grudem succinctly summarizes their main 
objections when he claims that adopting evolution leads to the following eight positions contrary to the teaching of the Bible:

(1) Adam and Eve were not the first human beings, but they were just two Neolithic farmers among about ten million other human beings on earth at that time, and God just chose to reveal himself to them in a personal way.

(2) Those other human beings had already been seeking to worship and serve God or gods in their own ways.

(3) Adam was not specially formed by God of dust from the ground (Genesis 2:7) but had two human parents.

(4) Eve was not directly made by God out of a 'rib that the Lord God had taken from the man’ (Genesis 2:22), but she also had two human parents.

(5) Many human beings both then and now are not descended from Adam and Eve.

(6) Adam and Eve's sin was not the first sin.

(7) Human physical death had occurred for thousands of years before Adam and Eve’s sin - it was part of the way living things had always existed.

(8) God did not impose any alteration in the natural world when he cursed the ground because of Adam's sin.

Grudem goes on to claim that evolution allows people to explain life without reference to God, with the result that God makes no difference at all. ${ }^{3}$

Many of the concerns raised by Grudem are legitimate, and given that the Bible is of central importance to the faith of Christians worldwide, the theory of evolution is unlikely to find widespread acceptance among Christians unless such concerns are seriously considered and adequately addressed. In this paper, I shall argue, vis-à-vis these eight positions, that there is no 
incompatibility with evolution even when a consistently literal reading of the relevant Biblical texts is maintained. But before I begin, I would like to make the following clarifications.

First, by 'evolution', I mean the process, involving the mechanisms of genetic mutation and natural selection, by which the present diversity of plant and animal life arose from a common ancestor. With this clarification, it should be evident that 'evolution' does not entail atheism; on the contrary it is compatible with divine intervention at various points of the universe's history and at the quantum level. For example, it is compatible with the view that God created the universe, fine-tuned its laws, created the first life, controlled the mutations of genes which appear to be random and the natural forces such that certain biological traits are selected (perhaps by acting at the quantum level), ${ }^{4}$ and (as will be explained further below) specially created the first human in His image. Thus understood, evolution is compatible with the Cosmological Argument as well as a number of other arguments for theism; ${ }^{5}$ it is even compatible with certain projects undertaken by members of the Intelligent Design movement, ${ }^{6}$ such as arguing that it is improbable that life originated without the supervisory control of a Designer. ${ }^{7}$ Therefore, it is not necessarily the case that believing in evolution allows people to explain life without reference to God or that God makes no difference at all, as Grudem alleges. Second, my argument is independent of whether evolution occurred or not. It should be noted that some scholars who have affirmed that evolution is compatible with biblical doctrines, such as William Lane Craig, have nevertheless expressed their scepticism concerning this theory on scientific grounds. ${ }^{8}$ My motivation for writing this article is primarily theological: regardless of whether one believes in evolution or not, one must be careful not to rule out evolution by saying that it is incompatible with the Bible when in fact such an incompatibility does not exist. (The error of ruling out a scientific theory by saying that it is incompatible with the Bible when 
in fact no such incompatibility exists has been committed by Christians over the centuries, often with disastrous consequences when the theory [e.g. Copernicus'] was subsequently vindicated by further evidences). On this point, one must be careful to note the distinction between (A) 'interpreting the Bible' (B) 'showing that the Biblical account is true', and (C) 'showing that there is no incompatibility between evolution and Bible'.

For (A), one might ask for positive evidence to show that a proposal is what the human Biblical author expresses, but for (C) it is perfectly legitimate to suggest a possible scenario which the Biblical authors may not have thought of, as long as the possibility is not contradictory to what the Biblical authors expressed. Compare this understanding with, for example, Peter Enns dismissal of all efforts to reconcile Genesis with evolution on the basis that these efforts produce a 'hybrid' Adam who is utterly foreign to the Biblical portrait and to the consciousness of the Biblical authors, ${ }^{9}$ and $\mathrm{H}$. Russman's objection that there is no Biblical mandate for the distinction (which I shall also make below) between Homo sapiens (the biological human species) and Homo divinus (mankind made in the image of God). ${ }^{10}$ Enn's dismissal is based on a misunderstanding of the intention of such efforts—such efforts do not have to be perceived as attempts to understand what the Biblical authors had in mind, but rather as attempts to show that evolution is not contradictory to what the Biblical authors expressed. It should be noted that the inerrantist's understanding of the doctrine of divine inspiration of Scripture which Grudem embraces does not require the human Biblical authors to be omniscient just as the Divine author is, and it does not require God to reveal to the human Biblical authors an exhaustive knowledge of everything (such as an exhaustive knowledge of Adam); it only requires that what is inspired is true (Evangelical Christian doctrine recognizes that the Bible is not intended to be an encyclopaedia of science. On the contrary there are Biblical principles which encourage people 
to study 'the works of the Lord' [Psalms 111:2], which would include the natural world given the Biblical affirmation of God as the creator of all things. According to this understanding, God did not provide an exhaustive knowledge of the natural world in the Bible, but encouraged people to study it and find out the details themselves). Given what is said above, it can be argued that the reason a 'hybrid Adam' does not feature in the Bible is not because the human Biblical authors rejected evolution but because they did not think about evolution at all. Hence we have to be careful about what the Bible does and does not say, and in this paper it will be argued that evolution is not contradictory to what the Bible does say about creation and other matters. While the evolutionary Adam suggested by such efforts may indeed not be what the Biblical authors had in mind nor what the Biblical authors mandated, 'not being what the Biblical authors had in mind nor what the Biblical authors mandated' is not the same as 'contradictory to what the Biblical authors expressed’.

Likewise, for (B), one would have to provide positive evidences (scientific, historical, etc) to show that the Biblical account is true, but for (C) it is sufficient to suggest a possible (not necessarily actual) evolutionary scenario that is not contradictory with positive evidences of science nor with plausible interpretations of the Bible and then say, 'for all we know, this is how it could have happened'.

Hence, for the purpose of this paper one does not need to provide positive scientific or Biblical evidence to show that the proposed evolutionary scenario is actual or what the Biblical authors had in mind, rather all that is required is to show that the proposed evolutionary scenario is not contradictory with positive scientific or Biblical evidences (note that 'positive' indicates 'evidences that we have' and not 'absence of evidence' unless there is good reason to think that the absence would not have been the case if the conclusion were otherwise). 
In what follows, I shall propose such an evolutionary scenario which addresses Grudem’s objections by incorporating insights from recent discussions in science and religion, philosophical theology and Biblical exegesis, as well as by making additional arguments of my own. While each of the points I raise might have been argued at greater length by other scholars before, there has been no systematic examination of the sort of agenda proposed by Grudem, hence the contribution of this article. While various interpretations of the Genesis text have been suggested in light of its genre, ${ }^{11}$ I shall show that there is no inconsistency between evolution and Biblical doctrines even when a consistently literal reading of the relevant Biblical texts is adopted. I intend 'consistently literal reading' to be understood in a non-pejorative sense in light of the history of literalist hermeneutics. Joshua Moritz helpfully explains this approach as follows:

'With regard to passages of scripture that are not obviously poetic or parable, the essence of biblical literalism consists in adopting a narrative approach to scripture (where the biblical text is basically read as an internally consistent narrative) and then going on to understand the details of the narrative as objectively true in the historical and scientific senses. This narrative-literal hermeneutic is a non-pejorative understanding of biblical literalism that I believe captures the core of what is going on in the minds of self- confessed scriptural literalists throughout Christian history. ${ }^{12}$

Note that the purpose here is not to defend the historical reliability of the Old and New Testament against critical historical scholarship (such projects have been undertaken by others), ${ }^{13}$ nor to argue that a consistently literal reading is necessarily the best. Rather it is to address the concerns of Grudem on his own grounds. The approach here is different from those proposals which embrace an 'accommodation of God' framework ${ }^{14}$ and reject the historicity of 
Adam, ${ }^{15}$ or those who think that certain descriptions (e.g. of farming) in Genesis (e.g. chapter 4) is not literal but anachronistic; ${ }^{16}$ I shall show that one does not need to go these routes in order to demonstrate that evolution is compatible with Biblical doctrines. I shall accomplish all of the above in the process of discussing the eight positions Grudem summarizes.

(1) Not all Christian evolutionists hold that Adam was a Neolithic farmer. There are some who deny the existence of Adam as a historical figure, claiming that the story in the first few chapters of Genesis is a myth which was written to provide a theological account of the role and importance of humankind in God's purpose, or a retelling of an episode or series of episodes of the beginning of humankind's turning to their Creator in their evolutionary history. ${ }^{17}$ However, many have pointed out that the identification of Adam as a single historical figure, just as Jesus is a single historical figure, is intrinsic to the logic of Romans 5:12-21 (see especially verses 14 and 17). ${ }^{18}$ Therefore, to deny the historical existence of Adam would be to deny the Biblical doctrine that is affirmed in Paul's Epistle to the Romans.

Grudem is responding to Christian theistic evolutionists like Alexander who would affirm the historical existence of Adam. Although 'anatomical Homo sapiens' (i.e. creatures with physical features that are identical with human beings') appeared in Africa about 200,000 years ago, evolutionists like Alexander postulate the time of Adam's creation to be about 10,000 BC during the Neolithic period because of the data concerning Cain and Abel in Genesis 4. (Archeologist Steven Mithen notes that soon after 10,000BC there was an astonishing spurt of global warming that brought the Ice Age to its close, and that there are evidences of the Neolithic culture in the Near East in 9600 BC). ${ }^{19}$ As geologist Davis Young argues,

'Cain is evidently the firstborn son of Adam and Eve. As befitted one who "worked the soil”, Cain brought an offering of the fruits of the soil. He sounds like a farmer, not simply a 
person who gathered wild fruits and vegetables. His brother Abel "kept flocks", and so brought an offering “of the firstborn of his flock”. He sounds like a shepherd. After Cain killed his brother, he escaped to the land of Nod, fathered his son Enoch, built a city, and named it after his son. At the very least he established some sort of permanent settlement. Within a few generations, the descendants of Cain were using musical instruments, working metal, and engaging in the nomadic herdsman lifestyle. Genesis 4 seems to describe the cultural achievements associated with the Neolithic revolution, evidence of which is preserved in archeological sites throughout the Near East.' 20

However, as Henri Blocher observes, the problem with the Neolithic Adam proposal is that it requires abandoning Adam's fatherhood of all present humans (the ancestors of present populations were scattered on the various continents long before the Neolithic age

Blocher suggests that Adam could be placed well before the Neolithic period (perhaps even before 100,000 years ago), arguing that the low level of cultural achievements during the many subsequent millennia prior to the Neolithic can be interpreted as the effect of degeneracy. ${ }^{21}$ Likewise, Gavin Basil McGrath, who also dates Adam way before the Neolithic period, also proposes 'the existence of civilizations that collapsed and were followed by uncivilized societies. For example, the Myan civilizations of ancient Central America collapsed, and from their ruins came some uncivilized people encountered by the Spanish Conquistadors; or the white man found only tribal Africans living near the collapsed Zimbabwe civilization.' ${ }^{22}$ Palaeontologist Chris Stringer notes the importance of climate and population densities for technological advancement and the potential to express and accumulate 'signals of modernity., 23 It could be that long periods of harsh climate during the Last Glacial Period (110,000 to 10,000 
years ago) and/or decrease in population densities due to catastrophic events caused the degeneracy.

One might object that there is no evidence of such advanced cultures prior to the Neolithic nor evidence of subsequent collapse. In response, as noted previously, to show that evolution is compatible with Biblical doctrines, it is sufficient to suggest a possible (not necessarily actual) evolutionary scenario and then say, 'for all we know, this is how it could have happened'. The 'in-compatibilists' would then need to bear the burden of proof to exclude the possible scenario that I am suggesting here in order to conclude that evolution is incompatible with Biblical doctrines. For the 'compatibilists' case, it can be argued that, possibly, the periods of more advanced culture prior to the Neolithic were relatively too short and limited in scope to have left traces in the archaeological record, and that the evidences that we do have concerning human evolution are still vastly incomplete and hence the possibility suggested here cannot be ruled out. In this case, the absence of proof is not proof of absence.

In view of the above possibilities, I agree with Blocher that 'in the present state of knowledge, Adam is hard to locate in the prehistorians schemes'. Contrary to the charge of Grudem I shall argue that Adam and Eve were the first human beings, but this does not require Adam to be the first anatomical Homo sapiens. The key issue is how 'human beings' are defined. Christian theology has traditionally understood that what is essential to 'human beings' is that they possessed the image of God (Genesis 1:26-28, 5:1-3, 9:6), which implies that a human being is a representation of God. ${ }^{24}$ In his important study on the Imago Dei, Richard Middleton explains that understood in its Jewish and ancient Near Eastern context tselem, the Hebrew word for 'image' should be understood as a localized, visible, corporeal representation of the divine. He notes that the point here is not that the image consists in a bodily resemblance between God 
and humanity. A virtual consensus among Old Testament scholars concerning the meaning of the imago Dei in Genesis sees the image of God as the royal function or office of human beings as God's representatives and agents in the world, given authorized power to share in God's rule over the earth’s resources and creatures. ${ }^{25}$ On Genesis 1:26-8 Old Testament scholar Richard Hess observes that one of the ways to understand 'to rule' and 'to exercise dominion' is by looking at what the man does in Genesis chapter 2: working and taking care of the garden so that it would fulfil its purpose and bear fruit (2:15), naming the animals and discerning their purpose and function (2:19-20). ${ }^{26}$ God's command to human beings to subdue the earth and have dominion over the fish of the sea and over the birds of the heavens and over every living thing that moves on the earth (Genesis 1:28, cf. Psalms 8:6-8) can be understood as a command to actualize the potential for this kind of dominion, and the nature of the command implies the potential for a sense of responsibility for it. A possible scenario, therefore, is to understand the potential for a unique kind of dominion that could extend to the whole world and over all kinds of creatures, and the potential for a sense of responsibility towards God for this kind of dominion, as aspects of the uniqueness of human beings. (This does not imply that every human would actualise these potentials in this life [e.g. people who suffered from brain injury or are born mentally handicapped would not], but that the potential would be found in the human race, among Adam and his descendents who would be fruitful and multiply, fill the earth and subdue it).

Objecting to this kind of view and going against the views of many theologians, Moritz argues that the Imago Dei should not be understood as ontological uniqueness. He proposes that human uniqueness should be understood as God's election of humans for the role of royal representatives. ${ }^{27}$ 
In response, I do not disagree that human uniqueness includes God's election of humans for the role of royal representatives, but I think ontological uniqueness cannot be excluded as well. Citing Old Testament scholar Phyllis A. Bird, Moritz argues that the biblical context of the designation, "image and likeness of God," makes it plain that its theological significance is in the place it gives to humans within the created order, and not in any physical or moral attributes of the species, in either its present or "original” state. ${ }^{28}$ In response, I agree with the theological significance concerning the place given to humans within the created order, but I do not think that the Old Testament authors exclude attributes of human beings as part of their uniqueness. As argued previously, to show that evolution is compatible with Biblical doctrines all that is required is to come up with a possible scenario, not necessarily one which the Old Testament authors had in mind, and it is a possible scenario that God gave human beings certain unique capacities so that they could fulfil their unique role which they have been elected for (it is interesting to note that in the Old Testament there are examples where God gave certain people certain unique capacities [which people around them did not have] to fulfil what He called them to do, see e.g. Exodus 31:6).

Moritz is concerned by the arguments that empirical studies have not clearly shown that non-human animals lack all of the human capacities and characteristics, that empirical investigations have shown that various non-human animals have capacities and behaviors once thought to be uniquely human and vindicated Darwin's views on human-animal continuity, that remaining empirical gaps might be closed through future scientific research, and that the early hominids such as Homo erectus, Homo neanderthalensis and Homo floresiensis were like homo sapiens in virtually every conceivable respect, and yet members of distinct species. On the last point he observes 
'While we know little about the daily lives of individuals from these distinct human-like species, we are nevertheless able to ascertain from their material remains and artifacts that they were accomplished bearers of culture, technology, art, jewelry, and music, that they created and used sophisticated tools such as scrapers, knives, hand axes, and in some cases composite throwing spears; that they mastered the use of fire; that they constructed shelters with hearths; and that they at times built boats for the purpose of seafaring. There is clear evidence that at least one of these non-human species ritually buried their dead, and many paleoanthropologists have argued that all of these hominids used a type of language akin to that of their human cousins. In addition to this, the respective cranial volumes of these extinct hominids place all but one of them within the cranial volume range of $90 \%$ of modern humans. ${ }^{29}$

Moritz’s concerns are well taken. Nevertheless, as explained previously for the purpose of this paper one only has to suggest a possible scenario. Thus one does not have to provide empirical evidence that clearly show that non-human animals lack all of the human capacities and characteristics, but only that the possible scenario has not been excluded. As for the empirical investigations which Moritz thinks have shown that various non-human animals have capacities and behaviors once thought to be uniquely human, ${ }^{30}$ the capacities and behaviors revealed by these investigations are rather rudimentary in comparison with those of the early hominids noted above. The latter exhibited far more advanced capacities such as the ability to use sophisticated tools and ritually buried their dead, but even these fall short of indicating a dominion that could extend to the whole world and over all kinds of creatures, and a sense of responsibility towards God for this kind of dominion. It may be, as Darwin stated and Moritz noted, that viewed from a certain perspective 'the difference...between man and the higher animals, great as it is, certainly is one of degree and not of kind. ${ }^{31}$ However, one might argue 
that difference in degree is a significant ontological difference beyond a certain threshold, and the threshold here is the capacity for the unique dominion and responsibility towards God mentioned above. ${ }^{32}$ Opponents to this possible scenario may speculate that, had the other hominid species been given more time, they may also have developed sufficiently to demonstrate this capacity. However, to deny the viability of the possible scenario I am suggesting here, speculations are not enough; one needs to have evidence that this is indeed the case. Likewise, speculations about whether the remaining empirical gaps might be closed through future scientific research are not enough; until one actually close the gap, the scenario I suggest here remains a viable possibility (it should be noted that for the purpose of this paper I do not have to claim that the scenario I am suggesting cannot be falsified by future scientific discoveries; see the Conclusion of this paper). ${ }^{33}$

Going back to the Biblical narrative, it should be noted that, even if there is no evidence to show that Old Testament authors had attributes of human beings in mind when they talk about human uniqueness, the New Testament authors may have hinted at this when they talk about the image of God in relation to Jesus Christ as the perfect image of God (2 Corinthians 4:4, Colossians 1:15). In this case the possession of the image by humankind can be understood as the potential to be made to become conformed to the image of His Son (Romans 8:29), in particular to be Christ-like in their attitudes (Philippians 2:5). It has been argued that the image of God can be understood in different ways - as substantive, as functional, as relational, as eschatological. ${ }^{34}$ The possible scenario I am proposing here encompasses these aspects: the property of having the above mentioned potentials would be the substantive aspect, the exercise of these potentials in relation to creatures and in obedience to God would be the functional and 
relational aspects, and the actualization of these potentials over time and in the future kingdom (Revelation 5:10) would be the eschatological aspect.

Much more can be said about the image of God, but it is beyond the scope of this paper to discuss this further. For our present purposes here, according to the possible scenario I am proposing the properties of (i) having the potential for a unique kind of dominion that could extend to the whole world and over all kinds of creatures (ii) having the potential for a sense of responsibility for this kind of dominion, and (iii) having the potential to be made to become conformed to Christ would be some of the properties that differentiate human beings from animals which do not have the image of God. (Here potentials refer to capacities which can be actualised). It could be the case that these properties were directly and specially created by God on a pre-existing member of the hominid species. This results in a new, originally sinless person (Adam), who would be the first 'anatomical Homo sapiens' to have the image of God. Hence, Adam would be the first 'human being' or, to use John Stott's terminology, the first 'Homo divinus. ${ }^{35}$ The possession of the image of God is what made human beings special, even though their bodies do not appear to be special in comparison with other animals.

On the possible scenario I am suggesting, it is not true that Adam and Eve were 'among about ten million other human beings on earth at that time', as Grudem alleges. At the time of Adam's creation there were perhaps other 'anatomical Homo sapiens' around. Nevertheless, these other 'anatomical Homo sapiens' did not possess the image of God and hence were not truly human beings. The reason why they did not possess the image of God is because, while between them and Homo divinus there would be many similarities, both physical and behavioural, there would be differences in their capacities. The properties which are possessed by Homo divinus but not other 'anatomical Homo sapiens’ would include (as mentioned above) 
the potential for a unique kind of dominion that could extend to the whole world and over all kinds of plants and animals, the potential for a sense of responsibility towards God for this kind of dominion, and the potential to be made to become conformed to Christ (see further, (5)). Since the scenario I am proposing does not require Adam to be the first anatomical Homo sapiens, my scenario has no problems with the claims that studies of modern human genome indicate that the modern human population probably was never less than several thousand people at any time in its past, ${ }^{36}$ nor with the claims that there was genetic mixing between early modern humans and late surviving Neandertals, ${ }^{37}$ regardless of whether these claims are true or not.

(2) As argued above, the 'other human beings' around Adam should not be understood as human beings but 'anatomical Homo sapiens'. There are evidences that 'Homo sapiens' engaged in religious activities about 50,000 years ago, ${ }^{38}$ but this does not imply that they are necessarily human beings, for there is no Scriptural basis for asserting that only human beings are capable of religious behaviour. Recent studies have shown that there are glimmers of both free will and moral awareness in the other members of the animal kingdom. ${ }^{39}$ One has to be wary of concluding, based on previously unexamined presuppositions, that it is unacceptable to think that other animals (including 'anatomical Homo sapiens') could have certain limited forms of religious knowledge and expressions. Indeed, the idea that animals should have many capacities similar to human beings (except perhaps the potential for the unique dominion, responsibility and Christlikeness mentioned above in relation to the image of God) should be expected given Moritz's observation that in the Bible

'Both humans and animals are described as "living souls/living beings" (nephesh), and the word used here implies a certain kinship (for animals, see Gen. 1:20, 1:30, 2:19, 9:4 and for humans, see Gen. 2:7, 9:5, 12:5). The word "spirit" (neshama) is also used in reference to both 
humans and animals (Gen. 6:17, 7:22). Other biblical Hebrew terms also reflect this similarity between humans and animals. The phrase "spirit of life" (ruach hayyim) is used for both animals and humans without distinction (for animals see Gen. 1:20-24, 2:19, 9:10, 15; for humans, see Gen. 2:7, 9:5). The word "flesh" (basar) includes both humans and animals. The expression "all flesh” (kol basar) literally means “all living creatures, animal as well as human.” In Scripture, there is only one designation that humans unequivocally have and that animals do not: humans, unlike animals, are said to be created "as the image and likeness of God" (imago Dei). ${ }^{40}$

The neglect of the Biblical description of the points of similarities between humans and animals by many evangelical Christians has resulted in the distinction between human beings and animals being overdrawn, leading to an unnecessary rejection of evolutionary scenarios.

(3) Genesis 2:7: 'Then the LORD God formed the man of dust from the ground and breathed into his nostrils the breath of life, and the man became a living creature'(ESV).

Concerning this verse, it should first be observed that, before God breathed into the nostrils, the 'man' referred to in this verse was not a 'living creature', it was perhaps just a 'physical body' which was to become the body of a man. It was only after God breathed into the nostrils that the 'physical body' became a living creature. So where did the 'physical body' come from? The phrase '...of dust from the ground' can be understood as stating that all human bodies are made of the material to which they shall return when they die (cf. Genesis 3:19 'By the sweat of your face you shall eat bread until you return to the ground, for out of it you were taken; you are dust, and to dust you shall return'). The phrase does not carry any implication concerning the process by which the body was formed. The point of the author of Genesis is perhaps the vulnerability and unworthiness of human bodies in comparison with God (concerning 'dust', see Genesis 3:19, 3:23, 18:27; see also Psalms 103:14; 1 Corinthians 15:47). 'Formed' (Hebrew 
'yatsar') in this verse is consistent with the idea of making an already existing body which was 'made of dust' functional (i.e. with the capacity for possessing the image of God). The 'already existing body' could be the body of an 'anatomical Homo sapiens' which had just died, and which after God breathed into it became a 'living creature’ with the image of God. Contra Grudem, the 'parents' of Adam were not human beings but were 'anatomical Homo sapiens' since they did not have the image of God.

It should be noted that I do not reject the literal interpretation of Adam being formed specifically from dust. I only highlight that the formation of his body can take place over time through an evolutionary process. As Moritz observes concerning the Hebrew words yatsar, asah, and the Biblical description of the creation of animals and humans and the formation of human being in the womb (Psalm 139:13-16, Isaiah 44:24, Isaiah 49:5, 44:2),

'The same Hebrew words (yatsar and asah) which describe the 9-month-long process of development from two single cells to a fully formed human being is used to describe the earth's creation of the different types of animals in direct response to God's command. In other words, in the emergence of plant and animal life through earth history, we find the same general trajectory as in the formation of an embryo in the womb: first single cells, then multicellularity, and then more complex organisms... the exact same Hebrew words (asah and yatsar) that describe God's forming of embryos in the womb, and God's forming of plant and animal life, are used to describe God's forming of the human species. The use of these words implies (or at the very least, does not rule out) that God's forming of humankind was a process and not an instantaneous event. $^{41}$

(4) The scenario which I am sketching does not exclude the possibility of Eve being specially created by God using Adam's rib. ${ }^{42}$ As in the case of Adam being formed from dust by 
God, I see no reason to reject a literal interpretation of this. In both cases the interpretation is allowable by a literal reading of the text, as well as a physical understanding of it, and in both cases the interpretation is compatible with evolution. One might object that pre-Adamic sexual differentiation was already present in the anatomical homo sapiens, and insists that the miraculous creation of Eve's physical body is inconsistent with the creation of Adam who was anatomically descended from previous anatomical homo sapiens. Nevertheless, these reasons are inadequate for excluding the possibility that God could have chosen to do a miracle in Eve's case to illustrate to her and Adam that she is intended to be a close and intimate companion by his side.

(5) As explained above, according to my scenario all 'anatomical Homo sapiens who have the image of God' are the descendants of Adam and Eve, and that it was through Adam's disobedience that sin entered into the human race (Romans 5:12-21).

(6) My scenario affirms that the sin of Adam and Eve was the first sin committed by human beings, regardless of whether there were sin committed by 'anatomical homo sapiens' before that (as noted previously in (2), non-human beings may have moral awareness), since 'anatomical homo sapiens' are not human beings. There is no passage in the Scripture which indicates that the sin of Adam and Eve was the first sin in the universe. On the contrary Christians have traditionally thought that Satan sinned before Adam and Eve; in any case Genesis 3 portrays that the snake which tempted Eve in the Garden of Eden had certain knowledge of God and that it chose to sin before Adam and Eve did by tempting them.

(7) According to the scenario I am sketching, death (though not to Homo divinus) had indeed occurred before Adam. Scriptural passages such as Romans 5:12-21 pose no insurmountable problem to my view, for they can be understood as affirming that death to 
human beings (rather than death in general) came as a consequence of Adam. ${ }^{43}$ It has been argued that the view that suffering and death occurred before Adam is incompatible with belief in the goodness of God's original creation and the belief that suffering and death are the result of $\sin { }^{44}$ The following replies may be given.

First, for all we know the culpability for suffering and death before Adam could be traced to the moral wrongdoing of certain free creatures such as angels. ${ }^{45}$ For example, it could be that angels who chose to sin (e.g. Satan) distorted God's original creation by causing mutations that resulted in suffering, but God worked good out of the evil they caused by using suffering and death to evolve higher-ordered life. ${ }^{46}$ There are interpretations of the first chapters of Genesis which are compatible with this view. For example, according to Walton's 'Functional Creation' view, the Seven Days of Genesis 1 could be understood as seven 24-hour periods in which the universe with the pre-existent stars and planets (including the environment of planet earth) and living things were organized (or re-organized) by God to function in a way that was ideal for the appearance of the first humans, who with the organized universe formed a cosmic temple which God called 'good' (Genesis 1:31). Walton argues that the Hebrew word bara which is translated as 'create' in Genesis 1 can be taken to mean functional (with respect to the cosmic temple) rather than ontological creation (hence, the apparent inconsistency between the chronological sequence of Genesis and evolutionary science [e.g. concerning whether the earth or the sun was made first] can be easily resolved). ${ }^{47}$ Walton emphasizes that his view does not deny that God is the first cause of the beginning of existence of the universe, noting that there are other passages in the Bible (e.g. Colossians 1:16-17) which affirm God's ontological creation of the material cosmos. ${ }^{48}$ The implication of Walton's view is that Genesis does not say when the universe (with the sun, the moon, the stars, and the living things) began to exist. It could have been millions or 
billions of years (during which God worked out His purposes for other creatures [e.g. angelic beings] while causing life to evolve), and then a reorganization just before the creation of the first humans. The author of Genesis does not tell us why the earth was 'formless and void and darkness was over the surface of the deep’ (Genesis 1:2) at the beginning of the Seven Days, nevertheless Walton's view is not contradictory with the view that this state of the earth was the result of destruction caused by fallen angels (though Walton does not mention this).

Second, it should be noted that many creatures which do not have a nervous system do not suffer pain. As for those which do have a nervous system, it could be the case that for many of them the nervous system would only cause them to have information concerning a harmful situation and that unknown to us they do not truly suffer phenomenological pain. ${ }^{49}$ As Ernest Lucas observes, since we do not know what goes on in the minds of prey and predator or of an injured animal, it is not clear how terms such as 'cruelty' or 'suffering' can be used of them. ${ }^{50}$

Third, for those that truly suffer phenomenological pain (e.g. perhaps the early hominids), it could be that these suffering would ultimately work for the good of these creatures. For all we know, these creatures might enter into an afterlife, in which they may at least be compensated for any suffering. ${ }^{51}$ It is important to note that according to the Scriptures Christ's death has the potential to reconcile all things to the Father (Col 1: 20). Based on passages such as Isaiah 11:6, 65:25 and Romans 8:19-22, a number of prominent theologians such as John Wesley, John Calvin, Martin Luther have held that other animals would be redeemed in the future. ${ }^{52}$ These animals may well include those hominids which did not have the image of God.

(8) The cursing of the ground by God because of Adam's sin can be understood in functional terms, i.e. the ground was cursed with respect to Adam. Gavin McGrath suggests that 
'In the first Eden and its environs, death was unknown (Gen. 2:17), humans were vegetarians (Gen. 1:29), and so were the animals (Gen. 1:30)...There is ample evidence in the fossil record of carnivorous and omnivorous animals existing before the time of Adam and Eve. This is not problematic if Eden and its environs was a segregated geographical area rather than a planetary-wide phenomenon, a view supported by Gen. 2:10-14... Because the reference to vegetarian animals is placed after the focus on the creation of humans (Gen. 1:26-30), rather than after the focus on the animals (Gen. 1:20-25), I think this lends itself to the interpretation that these vegetarian animals are those of the humans' world, i.e., Eden and its environs, rather than the larger planetary world. ${ }^{53}$

In other words, after his creation Adam was placed in a divinely protected environment (Eden) which occupied a limited geographical area on the earth, but after he sinned the ground on which he lived was cursed in the sense that it no longer had that divine protection. Concerning the Historical fall, Blocher wisely observes that,

'The data which might present some degree of relevance are few and meagre...The lack of vestigial from an Edenic state, however, should not surprise and embarrass believers. Even if that state was enjoyed for some time (years and not hours as some have thought), the chances of finding convincing traces are practically nil. The absence of proof is no proof of absence. ${ }^{54}$

\section{CONCLUSION}

With respect to the concerns of many Christians today, it has been shown that there is no incompatibility between evolution and Biblical doctrines, even when a consistently literal reading of the relevant Biblical texts is adopted. Concerning the relationship between the Bible's account of Adam and Eve and human evolution, Alexander points out that 'We really don't 
know the precise answer. There are simply too many unknowns in both the evolutionary account, and in our own interpretation of Scripture, to be dogmatic on this issue., ${ }^{55}$ Is it possible that the possible scenario I suggested might be falsified by future scientific discoveries? Of course. But there is currently no adequate reason for thinking that there could not be other scenarios which would be consistent with such discoveries and with plausible interpretations of the Bible, and hence no adequate reason for thinking that such discoveries would be inconsistent with the Bible. The value of my present proposal lies in showing the falsity of the widespread belief that current evolutionary science is contradictory to what the Bible says about creation and other matters. ${ }^{56}$

\section{ENDNOTES}

\footnotetext{
${ }^{1}$ Interview by Howard Condor on Revelation TV, UK, March 2011.

${ }^{2}$ It should be noted, however, that Christians from a wide variety of denominational perspective have been divided over evolution since 1859, and it may come as a surprise for many that a number of leaders of the 'Fundamentalist' movement such as Benjamin Warfield actually subscribed to a form of theistic evolution. See Alistair Donald, "Evolution and the Church,” in Should Christians Embrace Evolution?: Biblical and Scientific Responses ed. Norman Nevin (Nottingham: Inter-Varsity Press), 15-19.

${ }^{3}$ Wayne Grudem, “Foreword,” in Should Christians Embrace Evolution?: Biblical and Scientific Responses ed. Norman Nevin (Nottingham: Inter-Varsity Press, 2009), 9-10.

${ }^{4}$ Robert Russell, “Special Providence and Genetic Mutation: A New Defense of Theistic Evolution,” in Evolutionary and Molecular Biology: Scientific Perspectives on Divine Action, ed. R.J. Russell, W.R. Stoeger, SJ, and F. Ayala, 191-223 (Vatican City, Vatican Observatory and Berkeley, CA: Center for Theology and the Natural Sciences, 1998).

${ }^{5}$ William Lane Craig and J. P. Moreland eds., The Blackwell Companion to Natural Theology (Chichester, U.K.; Malden, MA, Wiley-Blackwell, 2009).

${ }^{6}$ As observed by Intelligent Design advocate Jay Richards in God and Evolution: Protestants, Catholics, and Jews explore Darwin's challenge to faith (Seattle: Discovery Institute Press, 2010).

${ }^{7}$ Stephen Meyer, Signature in the Cell: DNA and the Evidence for Intelligent Design (New York: HarperOne, 2009).

${ }^{8}$ http://www.reasonablefaith.org/scepticism-about-the-neo-darwinian-paradigm .

${ }_{9}$ Peter Enns, The Evolution of Adam: What the Bible Does and Doesn't Say about Human Origins (Grand Rapids: Brazos Press, 2012), xiv-xv, xvii.

${ }^{10}$ H. Russman, 'Correspondence,' Science and Christian Belief 12 (2000):165-171.

${ }^{11}$ Richard Hess, 'God and origins: interpreting the early chapters of Genesis' in Darwin, Creation and the Fall: Theological Challenges ed. RJ Berry and Thomas Noble (Nottingham: Apollos, 2009).

12 Joshua Moritz, 'The Search for Adam Revisited: Evolution, Biblical Literalism, and the Question of Human Uniqueness,' Theology and Science 9 (2011):370-371.

${ }^{13}$ See, for example, Kenneth Kitchen, On the Reliability of the Old Testament (Grand Rapids: Eerdmans, 2003); Steven Cowan and Terry Wilder, eds., In Defense of the Bible: A Comprehensive Apologetic for the Authority of Scripture (Nashville: B\&H Academic, 2013).

14 Theologians have observed that there are Scriptural passages which say that God has eyes, mouth, hands, wings, etc (e.g. Proverbs 15:3), but these should not be taken literally. Rather, they think that these should be understood as
} 
God taking into account the limitation of human understanding and therefore accommodated Himself in using the modes of expression and understanding of people of the past so that they could understand certain aspects of spiritual truths. See Alister McGrath, Science and Religion: An Introduction (Oxford: Blackwell, 1999), 9-15.

${ }^{15}$ E.g. Denis Lamoureux, Evolutionary Creation: A Christian Approach to Evolution (Cambridge, U.K.: Lutterworth Press, 2008); Enns, The Evolution of Adam.

${ }^{16}$ C.J. Collins, Did Adam and Eve Really Exist? (Nottingham: Intervarsity Press, 2011), 113.

${ }^{17}$ These views are discussed in Dennis Alexander, Creation or Evolution - Do We Have to Choose? (Oxford: Monarch, 2008), 235.

${ }^{18}$ E.g. Ibid., 265.

${ }^{19}$ Steven Mithen, After the Ice: A Global Human History, 20,000-5000 BC (London: Phoenix, 2004), 4, 56.

${ }^{20}$ Davis Young, "The antiquity and the unity of the human race revisited," Christian Scholar's Review 24 (1995): 380-396.

${ }^{21}$ Blocher, "The theology of the fall and the origins of evil", 170-172.

${ }^{22}$ Gavin Basil McGrath, "Soteriology: Adam and the Fall," Perspectives on Science and Christian Faith 49 (1997): 252-263.

${ }^{23}$ Stringer, The Origin of Our Species, 237-8.

${ }^{24}$ Anthony Hoekema, Created in God's Image (Grand Rapids: Eerdmans, 1986), 11-19.

${ }^{25}$ Richard Middleton, The Liberating Image: The Imago Dei in Genesis 1 (Grand Rapids: Brazos, 2006), 24-27 and n.32.

${ }^{26}$ Hess, “God and origins”, 95-6.

${ }^{27}$ Joshua Moritz, "Evolution, the End of Human Uniqueness, and the Election of the Imago Dei,” Theology and Science 9 (2011): 307-339.

${ }^{28}$ Joshua Moritz, “God's Creation Through Evolution and the Language of Scripture,” Theology and Science 11 (2013):1-7.

${ }^{29}$ Moritz, "Evolution”, 312-317.

${ }^{30}$ Ibid., n.35.

${ }^{31}$ Ibid, 313.

${ }^{32}$ My argument has some parallel with Timothy Williamson's reply to the sorites paradox, which claims that one grain of wheat does not constitute a heap, adding one more does not, adding two more do not, etc, and concludes that no amount of grains can constitute a heap. Williamson replies that the term 'heap' is semantically determinate and there is a sharp cut-off point at which the grains do constitute a heap, even though we might not know what the precise point is (see his Vagueness, [London: Routledge, 1994], Chapters 7-8, and Knowledge and its Limits [Oxford: Oxford University Press, 2000]). Here I am claiming that the cut-off point is the capacity for the unique dominion and responsibility to God mentioned above.

${ }^{33}$ Such gaps in evidence can legitimately be interpreted in a number of ways. Here I am employing a similar strategy - though with a different conclusion — as Moritz in his article "Human Uniqueness, the Other Hominids, and 'Anthropocentrism of the Gaps' in the Religion and Science Dialogue," Zygon: Journal of Religion and Science 47 (1), March 2012.

${ }^{34} \mathrm{~J}$. Wentzel van Huyssteen, Alone in the World: Human Uniqueness in Science and Theology, The Gifford Lectures, University of Edinburgh Spring 2004 (Grand Rapids: Eerdmans, 2006).

${ }^{35}$ John Stott, Understanding the Bible (London: Scripture Union, 1972), 63.

${ }^{36}$ Dennis Venema, "Genesis and the genome: genomics evidence for human-ape common ancestry and ancestral hominid population sizes,” Perspectives on Science and Christian Faith, 62 (2010): 166-178.

${ }^{37}$ Richard Green et al., “A Draft Sequence of the Neandertal Genome,” Science vol. 328 no.5979 (2010): 710-722.

${ }^{38}$ Chris Scarre, "Religion," in The Oxford Companion to Archaeology ed. Brian M. Fagan (Oxford: Oxford University Press, 1996).

${ }^{39}$ Peter Enns, Alister McGrath, and Jeff Schloss, "At what point in the evolutionary process did humans attain the 'Image of God'?” The BioLogos Forum (2011), http://biologos.org/questions/image-of-god).

${ }^{40}$ Moritz, "God's Creation Through Evolution and the Language of Scripture."

${ }^{41}$ Moritz, "God's Creation Through Evolution and the Language of Scripture."

${ }^{42}$ The fact that men and women have the same number of ribs does not contradict this, for the 'surgery' on Adam's rib would not have affected his genetic constitution and hence had no effect on subsequent generations of males.

${ }^{43}$ Adam's sin resulted in physical and spiritual death, the latter referring to alienation from God.

${ }^{44}$ Grudem, "Forward". 
${ }^{45}$ Michael Murray, Nature Red in Tooth and Claw: Theism and the Problem of Animal Suffering (Oxford: Oxford University Press, 2008), 6, 96-106.

${ }^{46}$ One might complain that the hypothesis that the "angels who chose to sin (e.g. Satan) distorted God's original creation by causing mutations" is completely unsubstantiated by anything in scripture or biology. In response, as argued previously, to show that evolution is compatible with Biblical doctrines one does not need to substantiate a hypothesis with positive evidences to show that it actually occurred, rather it is sufficient to suggest a possible (not necessarily actual) evolutionary scenario that is not contradictory to the findings of science and with plausible interpretations of the Bible.

${ }^{47}$ John Walton, The Lost World of Genesis One: Ancient Cosmology and the Origins Debate (Downers Grove: IVP Academic, 2009). Citing Walton's views concerning function does not imply that Walton and I agree on everything concerning the interpretation of Genesis; while Walton's view does not necessarily require a literal reading of Genesis, what I am arguing here is that there is no incompatibility with evolution even if the relevant passages are interpreted literally.

${ }^{48}$ Ibid., 97.

${ }^{49}$ Murray, Nature Red in Tooth and Claw, 41-72.

${ }^{50}$ Ernest Lucas, Can we believe Genesis today?: The Bible and the questions of science (Leicester: Inter-Varsity, 2001, 88).

${ }^{51}$ As argued previously, there is no need to justify such possibilities by citing passages in the scriptures; rather one only needs to say that this possibility has not been ruled out.

${ }_{52}^{5}$ Murray, Nature Red in Tooth and Claw, 122-129.

${ }^{53}$ McGrath, "Soteriology: Adam and the Fall”.

${ }^{54}$ Blocher, "The theology of the fall and the origins of evil", 169-170.

${ }_{55}^{55}$ Alexander, Creation or Evolution, 234.

${ }^{56}$ I would like to thank Professor James Peterson and Professor John Walton for fruitful discussions on related issues, as well as the editor (Professor Joshua Moritz) and anonymous referees for Theology and Science journal for their helpful comments. 